\title{
1. The books on social entrepreneurship we edit, critique and imagine
}

\author{
Chris Steyaert and Pascal Dey
}

\section{INTRODUCTION}

Social entrepreneurship is commonly (re)presented as the portent of a new era in which entrepreneurship is no longer reduced to its 'economic function' but is now seen as a 'pathway for social change' (Luke and Chu, 2013). This is an incisive assessment, one that we think deserves critical scrutiny. Thus, to all those who have wanted to embark on the path of social entrepreneurship, or who are simply curious to hear more about the buzz surrounding social entrepreneurship (Mauksch, 2014), we say be aware: we need critique, and we need it now! This is not, we argue, to divert attention away from the scientific project of social entrepreneurship research (Nicholls, 2010), and especially not to discredit social entrepreneurship tout court. Rather, the need and, indeed, the urgency of critique are grounded in the realization that a variety of things are wrong with social entrepreneurship: 'wrong' in both an epistemological sense (for example detached research practices and methodologies which fail to engage with the vagaries of everyday life and the moral and political predicaments of social entrepreneurship) and an ontological sense (for example misguided assumptions about the 'essence' of social entrepreneurship, such as atomism).

This book - Social Entrepreneurship: An Affirmative Critique - presents a range of critical approaches that we hope will interrogate, irritate and reimagine social entrepreneurship. While most of us already have our own understanding of 'critique' (Butler, 2001), it is important to note that this book does not address critique as something fixed or dogmatic (that is, critique as a narrow doctrine authoritatively defined by a particular group such as orthodox 'Marxists' or 'Trotskyists'). Instead of trying to set the universal standards for critique qua judgment, the chapters assembled in this book suggest various forms of critique to slow down any easy presumption about social entrepreneurship's essentially transformational 
benefit to society. But even if we do not define critique in relation to particular authors, styles or disciplinary origins, the individual chapters in this book share affirmation as their common denominator (Dey and Steyaert, 2010; 2015; Hjorth, 2017; Steyaert and Dey, 2010; Steyaert et al., 2017; Weiskopf and Steyaert, 2009). The guiding idea of critique as affirmation, broadly defined, is that social entrepreneurship is 'inadequate yet necessary'. That is, affirmation deems social entrepreneurship 'inadequate' in the sense that orthodox conceptions of the term remain overly wedded to issues pertaining to heroism, the non-political, the post-ideological, the 'objective' and 'value-free'; on the other hand, social entrepreneurship remains 'necessary' since it contains the seeds of becoming the harbinger of a paradigm of radical becoming (Calás et al., this volume), emancipation (Rindova et al., 2009) and social creativity (Weiskopf and Steyaert, 2009). Keeping with the ethos of affirmative critique implies working 'creatively in and from (and hence not against) the structured field of social entrepreneurship studies' (Steyaert and Dey, 2010, p. 235), thus using critique as a means for unleashing the potentiality contained and 'silenced' by grand narratives (Dey and Steyaert, 2010). So conceived, affirmation acknowledges the need for a critical interrogation of the premises and guiding assumptions of social entrepreneurship, while simultaneously forcing us to retain a 'productive sense' of critique that remains open to creative and active interpretations which take social entrepreneurship beyond the influence of 'vigilant and insomniac rationality' (Deleuze and Guattari, 2000, p. 112).

Thus with a tiny ding, with a semibreve sniff of air, we make reference to Adorno's (1974) aphorism from his Minima Moralia, ${ }^{1}$ 'No emancipation without that of society' (p. 173) to disturb the (often) unison gospel that celebrates social entrepreneurship, and to formulate a 'moral minimum' from which to launch a critical reception. With a single scratch of the pen we aim to initiate a contrapuntal reading of social entrepreneurship, thus remaining mindful that one can hardly refute social entrepreneurship by simply hauling out trite allegations and accusations. What is needed instead is a critique governed by 'love', that is, one full of admiration and respect for the subject being scrutinized (Derrida, 1995), and one construed as a practice rather than as a judgment (Adorno, 1981). To work as a practice, critique needs to apprehend the ways in which social entrepreneurship as a category of thought is instituted, how it is ordered as a field of knowledge, and 'how what it suppresses returns, as it were, as its own constitutive occlusion' (Butler, 2001). The subtitle of Adorno's Minima Moralia is Reflections from Damaged Life or, as it has been rephrased in a more recent edition (Adorno, 2005), Reflections on a Damaged Life. That phrase provides a link to understanding the kind of sensibility underpinning critique as practice. 
And thus it is pertinent to provide a short excursus on the trajectory of Adorno's book. Adorno, in exile from Nazi Germany, and under the urging of Max Horkheimer, had relocated via New York to Los Angeles; there, in 1942 he started to write this diary-like book consisting of reflections, adages and aphorisms (Buchanan, 2010; Garber, 2003). Damaged as he felt for being in exile and for the atrocities his home nation was inflicting upon the world, and with that strength of observation typical for those in new, foreign circumstances, Adorno writes about everyday experiences - from relations to cars, refrigerators, toys and doorknobs, and to reflections on gift-giving, occultism, avarice, lying, marriage and tact (Jaeggi, 2005) - and connects the smallest changes in the everyday to the catastrophic events of his time. Therefore, Jaeggi (2005, p. 65) argues that Adorno's 'critique of the "organization of the world" here stands for a fundamental questioning of our relations to the world and ourselves as a whole, beginning from the most personal experiences and carried out in detail'.

This is how we envisage the critical operations in the various analyses of this book: not a priori judgments of social entrepreneurship performed from afar, but critique as intimately related to specific, phenomenological events and observations (and thus empirical contexts). Moreover, the contexts where social entrepreneurship operates - where there is poverty, inequality, analphabetism, illness, or other disaster - are also 'damaged', and thus the analyses ask equally that we question how to relate to them.

In this introductory chapter, we situate Social Entrepreneurship: An Affirmative Critique in three steps. First, we position this book against the backdrop of journal publishing which has developed as the dominant code of 'academic excellence', and explain the urgency of a critical publication on this topic, that has obtained 'a high profile' (O'Connor, 2006) in the world of wealthy business donors and is linked - rare as this may be for a (new) academic field - to the granting of a Nobel Prize (to Muhammad Yunus in 2006). Second, we will recapitulate how this book draws upon the critical reception of social entrepreneurship. Third, we will give an overview of the various chapters and the respective critical perspectives and themes they draw on and address. We are mindful that this book is but a fleeting beginning of a debate that will, hopefully, pick up speed as time elapses, but we hope the various chapters will create an opening for a more diligent critical take on how we study social entrepreneurship in the future.

\section{SOCIAL ENTREPRENEURSHIP THROUGH BOOKS}

The introduction of social entrepreneurship into the academic canon signified a utopian spot in time, a moment of seemingly unbound possibility. 
Emerging already onto the scene in the 1980s, social entrepreneurship coincided with hot debates about the environment, migration, food safety, global warming, poverty and social exclusion. During that period, when the welfare state model was increasingly falling out of favor, and when the public sphere was no longer seen as a reliable force of either societal production or protection, people turned toward social entrepreneurship as a market-based form of organizing with primarily social/ecological objectives.

It appears fair to state that social entrepreneurship, like so many other phenomena we think, talk and write about, is a product of its time, a product whose 'use value' has grown steadily since its inception. Mentioning time, we must be aware that the book you hold in your hands (or browse on Kindle or Google Books, for that matter) too has its time, and timing. One way to put it would be to say that this book is an anachronism, something which apparently comes at the wrong time, because it is so firmly at odds with the spectacle of social entrepreneurship enacted and epitomized through award ceremonies, academic conferences and even scholarly writings (see Mauksch, Chapter 8, this volume). And, as we publish a book in an era when academic journals take on fetish-like qualities, and when many have predicted the 'death of books', it is worth asking 'why another book?', and 'why now?'. Haven't universities and libraries become unable to buy them, and aren't publishers increasingly unable to sell them (Wolfe Thompson, 2002)? And in fact, aren't there too many books to begin with? As Barnaby Rich lamented a long time ago, '[o]ne of the diseases of this age is the multiplicity of books; they doth so overcharge the world that it is not able to digest the abundance of idle matter that is every day hatched and brought forth' (Barnaby Rich, 1611; quoted in De Solla Price, 1963, p.63).

These questions are of course rhetorical, since books certainly remain important. Indeed, we would even state that a book engaging critically with social entrepreneurship is long overdue, now that the subject matter has become so fashionable that it has become very difficult to challenge it. However, books are certainly not as self-evident as they once were, since journal publishing has become the primary currency of academic labor (not least in the business school context) which inter alia determines the 'value' of any given piece of research and, importantly, of the author who has produced it. Interestingly enough, while books are increasingly pushed to the margins of academic writing, it is conspicuous that the field of social entrepreneurship operates according to a slightly different dynamic. Sassmannshausen and Volkmann (2016) mention that, based on their recent citation analysis of social entrepreneurship publications, almost half of the most cited papers have not been published in journals but in books, raising doubts about the current (over-)rating of journal publications. A 
relatively new 'field' like social entrepreneurship cannot develop without a 'critical mass' of books that make it possible to explore and experiment with the contours of a 'new' phenomenon. The field of social entrepreneurship research, as these authors' investigation shows, has witnessed a steady swell of books being produced since the 1990s. While that swell gained momentum particularly after 2004, some of those books were more 'academic' (such as Ziegler's (2009) An Introduction to Social Entrepreneurship: Voices, Preconditions, Contexts) while others were more 'practical' (such as Emerson and Twersky's (1996) The New Social Entrepreneurs: The Success, Challenge and Lessons of Nonprofit Enterprise Creation).

We do not want to diminish the importance of journal articles and, with that, the new journals that have been founded in the meantime, such as Social Enterprise Journal (Emerald, since 2005), Journal of Enterprising Communities (Emerald, since 2007), and Journal of Social Entrepreneurship (Routledge, since 2010). Still, we believe a book has an advantage: it can offer an incisive and collective intervention in the ways a field seems to evolve by presenting a collection of contributions that can offer breadth and weight to develop alternative views. Or to be a bit hyperbolic for once, a book offers liberties in terms of both writing style and content, which journal publishing might not. This has been suggested by, amongst others, Alvesson and Gabriel (2013) who objected that journal publishing has become overly 'formulaic'; that is, articles in journals increasingly assume 'standardized forms and expressions, predictable structures and signposts, and even routine content [. . .] [which results in] an increasing uniformity of academic publications and a gradual disappearance of style, imagination, and surprise from academic journals' (p. 246). This statement is of course exaggerated; plenty of journal publications are not formulaic (Gabriel, 2016). Alvesson and Gabriel still have a point, however: journal publishing has cultivated, even if by accident rather than design, a series of stylistic and thematic norms which scholars tend to emulate in the hope that doing so will increase their chances of being published. Unfettered by such isomorphic pressures, books (or book chapters) have the power to 'recruit the reader's imagination by enlisting him or her in the 'performance of meaning under the guidance of the texts' (Bruner, 1986, p. 25). To show how our own book uses critique to spark the imagination of its readers, we will offer a deeper look at its timeliness, rationale and structural logic.

\section{A BOOK ON CRITIQUE}

Our book on critique on social entrepreneurship comes roughly ten years after a first wave of edited books was published in the mid-2000s 
(Sassmannshausen and Volkmann, 2016). Indeed, in 2006 alone, we saw no less than four edited books on this topic: Social Entrepreneurship: New Models of Sustainable Social Change edited by Alex Nicholls, Social Entrepreneurship edited by Johanna Mair, Jeffrey Robinson and Kai Hockerts, The New Social Entrepreneurship edited by Francesco Perrini and Entrepreneurship as Social Change edited by Chris Steyaert and Daniel Hjorth. These books have been attentive to multiple facets of the social entrepreneurship phenomenon, but none of them has shared an overarching commitment to critique (although critical impulses are manifest in various parts of these books; for example Cho, 2006; Nicholls and Cho, 2006; Steyaert and Hjorth, 2006). After more than three decades of sometimes highly functionalistic research, anecdotal evidence and 'best management' thinking, where social entrepreneurship has been touted as the paradigmatic organizational form for creating social change, it is no big leap to see this as an opportune moment for a critical book. The timing of this book, we think, can be expressed through the Greek term kairos, which indicates a suitable time for something to take place. While alluding to opportunity and the 'right time', kairos also implies an obligation, since one must not waste the chance that is placed in front of one. So conceived, our book treats kairos as an obligation to 'drive critique through' by actualizing the potential to break the chain of mere repetition, that is, 'more of the same' (more functionalism, more best-management recipes, more 'value-neutral' science, and so on). Although kairos suggests going against the grain of what already exists, it is worth emphasizing that critique as we envision it is not merely an antagonistic practice of resistance (Parker and Parker, 2017), but an essentially creative act which expands the registers of what is conceivable and doable. Our approach to critique is, as we said above, not programmatic in the sense of suggesting a singular understanding of 'criticalness'. The danger we identify with a programmatic approach is that social entrepreneurship is subjected to judgments which merely subsume the subject under pre-existing categories. Hence, we abstain from delineating 'critique' alongside grand schemes, programs or generalizable formulas; instead we see it as having a vital, prosaic quality (Steyaert, 2004) that resonates from and with the circumstances in which it happens. On this view, we accept that critique is polysemic and plurivocal - qualities reflected in the diversity of critical contributions united in this book. Thus our primary purpose with this book is to illustrate, based on imaginative theoretical and empirical contributions, how critical work can unleash novel and affirmative ways of thinking about and relating to social entrepreneurship.

Of course this book could have been structured in countless ways, but we chose to use what we call five forms of criticalness. ${ }^{2}$ These pertain to the testing of popular ideas and assumptions of social entrepreneurship 
(coined 'political representation and myth-busting'); the denaturalization of ideological representations of social entrepreneurship ('ideology and power effects'); the performative effect of language and situated action in social entrepreneurship ('performative enactments'); the identification of social entrepreneurship's normative (moral) foundation ('participation and democracy'); and finally the complex relationality of social entrepreneurship and its ability to shift what is thinkable and doable ('relationality and the possible'). We describe all these below. Assigning each chapter to one of the five perspectives permits us to put into sharper relief the specific focuses, objectives and assumptions of the individual chapters, while elucidating the family resemblance of the chapters grouped in each part by pinpointing the essential common feature through which they are connected (Wittgenstein, 2001).

For each of the five parts we asked an expert in that domain to write a reflective commentary. They could go about this freely: they could engage quite closely with the chapters (perform text exegesis), or write in a more essayistic genre. We are more than pleased with the final result as all the commentaries and reflections, in their own unique ways, have come to play a vital role in restating and accentuating the ideas, problems and arguments of the original chapters. Further, the commentaries worked to relate the two chapters of each part in ways that identify particularly intriguing points of debate, and sketch out productive avenues for prospective research.

\section{OVERVIEW OF THE BOOK}

Foucault (1974) famously pointed out that ' $[t]$ he frontiers of a book are never clear cut: beyond the title, the first lines and the last full stop, beyond its internal configuration and its autonomous form it is caught up in a system of references to other books, other texts, other sentences: it is a node within a network' (p. 23). This represents a perfect description of the present book, which we like to think of as an assemblage of chapters which are both interrelated and standalone. Hence, chapters are often connected to other chapters (as well as to texts outside this book; Kristeva, 1980) in multiple and intersecting ways. This means that the book can be read in a variety of ways: from the beginning to the end (linearly), from the end to the beginning (reverse linearly), in random order, or by following the various intertextual hints and cross-references which link individual chapters to other texts in multiple and intersecting ways. We are hardly prescribing how the individual parts of the book are 'used', but nevertheless want to sketch out the focuses of the five parts and the individual chapters. 


\section{Part I: Social Entrepreneurship, Political Representation and Myth-busting}

Part I is dedicated to critical analysis in the form of 'myth-busting'; it looks into how important ideas in the field of social entrepreneurship are based on unchallenged assumptions which might take on a mythological form as they become naturalized as established truths. Myth-busting is based on the assumption that reliance on such casual assumptions increases the risk that social entrepreneurship will be based on false premises. Critique through 'myth-busting' thus encompasses empirical endeavors that ask whether popular ideas (read doxa) about social entrepreneurship are merely tall tales or whether they are actually true.

A first example of myth-busting is offered in Chapter 2 by Simon Teasdale, Fergus Lyon and Robyn Owen, who unmask assumptions about the monumental growth of social enterprises that are widespread in UK government circles where social enterprise has for many years been a preferred object of government programs and policies. Official publications purport that the UK government, based upon one of the most advanced legal and financial social enterprise infrastructures in the world, has been able to spur phenomenal growth among such enterprises. The authors cast this claim into doubt by re-analyzing official growth numbers in the UK, and in particular the underlying definitions of 'social enterprise'. They suggest that the reported population of social entrepreneurial organizations does not correspond with actual changes in everyday reality; instead, it forms a methodological artifact reflecting particular political decisions and interests.

In Chapter 3, Janelle A. Kerlin and Tom H. Pollak tackle one of the most popular and powerful myths of the third sector: resource dependency theory (RDT), which argues that organizations' behavior is partly a function of the availability of resources. RDT has been (mis)used by some nonprofit scholars to imply a causal relationship between cutbacks in public spending and the emergence of social entrepreneurship in the non-profit sector. However, Kerlin and Pollak, drawing upon detailed quantitative analysis, come to a very different conclusion as they re-open the debate about the assumption that, despite the widely varied definitions of social entrepreneurship, most (academic) renditions gravitate toward the understanding that social enterprises are either exclusively or predominantly financed via commercial income. Drawing on large-scale statistical data, this chapter homes in on and thereby unmasks as unfounded the popular assumption that non-profit organizations mutate into social enterprises as soon as non-commercial sources of income, such as government grants and private donations, become less available.

In Chapter 4, Raymond Dart uses the two chapters by Teasdale et al. and Kerlin and Pollak as a springboard to address how myth-busting can 
undermine widely spread ideas. He looks toward the complex political and social contexts behind these widespread and inaccurate claims that encourage us to believe in some kind of Social Enterprise Revolution. Dart thus emphasizes the importance of casting doubt on claims about the exploding number of social enterprises, and about the non-profit sector systematically replacing lost governmental revenue with new commercial sources.

\section{Part II: Social Entrepreneurship, Ideology and Power Effects}

In Part II, we zoom in on demystification as a critical strategy geared toward debunking ideological renditions of social entrepreneurship. In contrast to the first part, which focuses mostly on the factual correctness of what is said about social entrepreneurship, this section is critically concerned with how ideology conditions social entrepreneurship according to the sectional interests of particularly powerful groups, and how these ideological representations in turn shape the actual practices of social entrepreneurs, policy makers, academics, and so on in determinate ways.

The focus of Chapter 5 by Chris Mason and Michael Moran is the ideological operation of social entrepreneurship in UK and Australian policy-making by the leaders of the two countries' Conservative parties. The authors explore the place of social enterprise in the Big Society: the policy philosophy that initially occupied the policy agenda of David Cameron in the UK and briefly of Tony Abbott in Australia. The chapter draws on Wingo's framework of 'veil politics' (Wingo, 2003) to present the social enterprise myth as aesthetic adornment, tempting wider engagement and also as idealization. By unpacking how political leaders in the two countries deployed social enterprise, the authors summon Derrida's concept of iterability to explain the different trajectories the social enterprise myth has taken in the two countries, as shown through the failed transition of the Big Society project from the UK to Australia.

Chapter 6 by Pascal Dey and Chris Steyaert conceptually advances three distinct understandings of myth and demystification, including a discussion of their inherent benefits and limitations. Specifically, the authors first consider the dominant understanding of myth as false explanation (see Part I above). They go on to present an ideological view of myth which construes social entrepreneurship as a contingent social achievement which is passed off as 'natural' (see Mason and Moran, in Chapter 5). The chapter's main contribution is its introducing 'demystification from below' as a form of critique which works through the dialectic tensions between ideology and utopia. Based on a study of non-profit practitioners, Dey and Steyaert illustrate how the local use of language simultaneously reproduces and transcends the myth of social entrepreneurship. 
Chapter 7 by Lew Perren builds on the themes of those two chapters while calling upon the semiological insights of Barthes (1972) to show that social entrepreneurship is a political myth that subtly frames capitalist thinking through a mind-controlling form of Orwellian 'doublethink' (Orwell, 1949). Perren concludes that evading such an intoxicating myth is problematic, but that Lakoff's (2004) notion of 'reframing' might offer some guidance as a means of ideological escape.

\section{Part III: Social Entrepreneurship and its Enactments}

In Part III, we find two chapters that approach social entrepreneurship not as a stable, pre-existing 'thing', but as a phenomenon that is brought into existence as it is enacted through particular 'doings' (practices) and 'sayings' (talk and text). Allowing for an anti-essentialist understanding of social entrepreneurship, these authors pay close attention to the intricate ways in which social entrepreneurship is enacted; this allows us better to appreciate the contingency of the concept, and to be critically sensitive to the omissions or 'absences' (Law, 2004) that prevailing enactments of social entrepreneurship necessarily (and sometimes deliberately) produce.

Chapter 8 by Stefanie Mauksch addresses the performative effects of social entrepreneurship. Following Judith Butler, Mauksch suggests that language - speaking about social entrepreneurship - is inextricably linked with existence - being or becoming a social entrepreneur. She suggests, in a truly Butlerian sense, that social entrepreneurship is a regulatory ideal: a ritualistic, reiterative and citational practice by which discourse produces the effects that it names. Her chapter draws on an ethnographic study of social business events to shed light on how a particular social entrepreneurial vision gains appeal as a realizable approach. Mauksch calls attention to the performativity involved in establishing social business as a viable alternative for organizing global business.

In Chapter 9, Pam Seanor questions the adequacy of academic narratives which frame trust in univocally positive terms by conceiving it as an essential lubricant in cooperative relationships between social enterprises and government. Based on interviews with social entrepreneurial practitioners and government officials in England, she demonstrates that trust, rather than forming a linear and stable 'thing', is a fluid, constantly changing and contested social practice. Shedding light on the co-implication of trust and control, and the ubiquity of distrust, 'calculative trust' and practitioner resistance, the chapter works as an injunction to rethink the centrality of trust in the everyday life of social enterprises.

In Chapter 10, Karin Berglund homes in on the performative role of compassion in recruiting people to engage in social entrepreneurial 
activities. Berglund offers a compelling case of how compassion enables social entrepreneurship discourses to prosper and multiply, while simultaneously precipitating dilemmas and troublesome situations: on the one hand, compassion is a key ingredient in alleviating suffering for the other; on the other hand, compassion is compatible with neoliberal government which aspires to nudge people toward particular actions by mobilizing their desires and passions.

\section{Part IV: Social Entrepreneurship, Participation and Democracy}

In Part IV, we present two chapters that address the relationship between social entrepreneurship and democracy. Reflecting social entrepreneurship in terms of its normative role in society, the emphasis of this part is placed squarely on the moral predicaments and limitations of social entrepreneurship as both a discourse and a practice. Considering participation and democracy as higher moral principles to which social enterprises should adhere at all times, this part takes an interest in both whether social entrepreneurial organizations already embrace normative principles of participation and democracy and why they ought to.

Acknowledging the difficulties arising when social enterprises aspire to instigate social change, in Chapter 11, Trish Ruebottom asks how social entrepreneurial organizations can guarantee that what they do is actually just. Drawing on Jürgen Habermas's discourse ethics, Ruebottom contends that processes of democratic deliberation within organizations work to keep in check the risks associated with the economic, cultural and political dimensions of social entrepreneurship. Identifying and elaborating on the main components of democratic deliberation, she suggests three elements - communicative education, reflexivity, and facilitation of the ideal speech situation - that allow social entrepreneurial organizations to establish a modus operandi which takes into account the viewpoints of the organizations' beneficiaries, thus facilitating their self-determination and participation.

Expanding her work on how social entrepreneurship leads to the marketization of the voluntary sector, in Chapter 12, Angela M. Eikenberry addresses whether and how social entrepreneurship can bring about democracy, as it tends less to foster mutual exchange and public deliberation, and more to inadvertently advance a political agenda of austerity cutbacks, deregulation and the contracting out of public services. She contends that even though social enterprises might foster some level of internal democracy (that is, democratic processes within individual organizations), they are ultimately limited in what they can contribute to democratic outcomes in a governance environment. 
In Chapter 13, Denise M. Horn accentuates the insights of the two chapters by contending that social entrepreneurship may lead to increased political empowerment only if human capabilities are fostered and states are willing to support these efforts. To Horn, social entrepreneurship must be viewed as an ethical and normative pursuit, one in which governments have a stake. Too often, however, scholars and practitioners tend to take for granted that social entrepreneurship will naturally lead to empowerment. Thus an intervention is also necessary: we must reinterpret the logic of 'empowerment' that underlies most development schemes and its relationship to democratization.

\section{Part V: Social Entrepreneurship, Relationality and the Possible}

The final part offers an affirmative take on critique to inquire into the new possibilities that social entrepreneurship can produce. Conceiving of social entrepreneurship as inherently relational, including both humans and non-human 'things', the kind of critique promoted in this part sets out to explore how social entrepreneurship works not as an individual-based endeavor (the 'hero entrepreneur') but as a distributed agency which creates systemic changes by reframing and reordering reality in radically new ways.

In Chapter 14, Victor J. Friedman, Israel Sykes and Markus Strauch use field theory to suggest that the creation of value through social entrepreneurship forms an ongoing, relational process of co-creation. After laying out the theoretical foundations of field theory, the authors use the case of Beit Issie Shapiro, an Israeli non-profit, to illustrate the complex construction processes which eventually transformed the field of services for children with developmental disabilities. Emphasizing how Beit Issie Shapiro expanded the realm of the possible for both disabled children and their families, while simultaneously changing the social imagery of 'disability', the authors yield a key insight: theories of social entrepreneurship should move beyond individual perspectives and instead recognize the ontological role of relationships in constructing the social reality in which we live.

Chapter 15 by Marta B. Calás, Seray Ergene and Linda Smircich repositions 'social entrepreneurship' in the contemporary context of the Anthropocene, when social, environmental and economic transformation will require fundamental changes in (human/anthropocentric) modes of being in the world. The authors engage with three bodies of literature - postcapitalism, new materialisms and posthumanism - to articulate a continuum of practices and entities they assemble as becoming-socialentrepreneurship. This assemblage holds the processes 
necessary to address the emergence of a post-anthropocentric world. The chapter's contribution is both theoretical and empirically grounded, offering specific examples with contrasting interpretations, from a negation of social entrepreneurship to a hopeful reading of its becoming-socialentrepreneurship.

Jenny Cameron in Chapter 16 closes the part (as well as the book) by reflecting on how a relational view of social entrepreneurship stimulates thought around forms of social change that radically shift what is thinkable and doable at any given time. Cameron further points out that a relational view of social entrepreneurship demonstrates the fecundity of using social research to grasp how changing frames enables us to realize the seemingly 'impossible'.

\section{NOTES}

1. Minima Moralia is Adorno's playful variation on Aristotle's Magna Moralia. It has to be 'noted' that a 'minim' is in musical terms a note played for half of its duration (Garber, 2003).

2. This section draws partially on the typology of critical approaches developed in Dey and Steyaert (2012).

\section{REFERENCES}

Adorno, Theodor W. (1974 [1951]), Minima Moralia: Reflections from Damaged Life, London: New Left Books.

Adorno, Theodor W. (1981), 'Cultural criticism and society', in Prisms, Cambridge, MA: MIT Press, pp. 17-34.

Adorno, Theodor W. (2005), Minima Moralia: Reflections on a Damaged Life, London: Verso.

Alvesson, Mats and Yiannis Gabriel (2013), 'Beyond formulaic research: In praise of greater diversity in organizational research and publications', Academy of Management Learning \& Education, 12 (2), 245-63.

Barthes, Roland (1972), Mythologies, London: Vintage Books.

Bruner, Jerome (1986), Actual Minds, Possible Worlds, Cambridge, MA: Harvard University Press.

Buchanan, Ian (2010), A Dictionary of Critical Theory, Oxford: Oxford University Press.

Butler, Judith (2001), What is Critique? An Essay on Foucault's Virtue, accessed at http://eipcp.net/transversal/0806/butler/en.

Cho, Albert H. (2006), 'Politics, values and social entrepreneurship: A critical appraisal', in Johanna Mair, Jeffrey Robinson and Kai Hockerts (eds), Social Entrepreneurship, Basingstoke: Palgrave Macmillan, pp. 34-56.

De Solla Price, Derek J. (1963), Little Science, Big Science, New York: Columbia University Press. 
Deleuze, Gilles and Felix Guattari (2000), Anti-Oedipus: Capitalism and Schizophrenia, Minneapolis, MN: University of Minnesota Press.

Derrida, Jacques (1995), Points - Interviews 1974-1994, Stanford, CA: Stanford University Press.

Dey, Pascal and Chris Steyaert (2010), 'The politics of narrating social entrepreneurship', Journal of Enterprising Communities: People and Places in the Global Economy, 1 (4), 85-108.

Dey, Pascal and Chris Steyaert (2012), 'Social entrepreneurship: Critique and the radical enactment of the social', Social Enterprise Journal, 8 (2), 90-107.

Dey, Pascal and Chris Steyaert (2015), 'Tracing imagination in the ethics of entrepreneurship: Toward a critical hermeneutic of imagination', in Alison Pullen and Carl Rhodes (eds), The Routledge Companion to Ethics, Politics and Organization, London: Routledge, pp. 231-48.

Foucault, Michel (1974), The Order of Things: An Archaeology of the Human Sciences, London: Routledge.

Gabriel, Yiannis (2016), 'The essay as an endangered species: Should we care?', Journal of Management Studies, 53 (2), 244-9.

Garber, Marjorie (2003), Quotation Marks, London: Routledge.

Hjorth, Daniel (2017), 'Critique nouvelle - an essay on affirmative-performative entrepreneurship research', Revue de l'Entrepreneuriat, 1 (16), 47-54.

Jaeggi, Rahel (2005), "No individual can resist": Minima Moralia as critique of forms of life', Constellations, 12 (1), 65-83.

Kristeva, Julia (1980), Desire in Language: A Semiotic Approach to Literature and Art, New York: Columbia University Press.

Lakoff, George (2004), Don't Think of an Elephant! Know your Values and Frame the Debate, White River Junction, VT: Chelsea Green Publishing Company.

Law, John (2004), After Method: Mess in Social Science Research, New York: Routledge.

Luke, Belinda G. and Vien Chu (2013), 'Social enterprise versus social entrepreneurship: An examination of the "why" and "how" in pursuing social change', International Small Business Journal, 31 (7), 764-84.

Mauksch, Stefanie (2014), 'More than "buzz": About the promise and practice of social entrepreneurship', Zeitschrift für Wirtschafts- und Unternehmensethik, 15 (1), 148-53.

Nicholls, Alex (2010), 'Institutionalizing social entrepreneurship in regulatory space: Reporting and disclosure by community interest companies', Accounting, Organizations and Society, 35 (4), 394-415.

Nicholls, Alex and Albert H. Cho (2006), 'Social entrepreneurship: The structuration of a field', in Alex Nicholls (ed.), Social Entrepreneurship: New Models of Sustainable Social Change, Oxford: Oxford University Press, pp. 99-118.

O'Connor, Ellen (2006), 'Location and relocation, visions and revisions: Opportunities for social entrepreneurship', in Chris Steyaert and Daniel Hjorth (eds), Entrepreneurship as Social Change, Cheltenham, UK and Northampton, MA, USA: Edward Elgar Publishing, pp. 79-96.

Orwell, George (1949 [2009]), Nineteen Eighty-Four, London: Penguin.

Parker, Simon and Martin Parker (2017), 'Antagonism, accommodation and agonism in Critical Management Studies: Alternative organizations as allies', Human Relations, 70 (11), 1366-87.

Rindova, Violina, Daved Barry and David J. Ketchen (2009), 'Entrepreneuring as emancipation', Academy of Management Review, 34 (3), 477-91. 
Sassmannshausen, Sean P. and Christine Volkmann (2016), 'The scientometrics of social entrepreneurship and its establishment as an academic field', Journal of Small Business Management, forthcoming.

Steyaert, Chris (2004), 'The prosaic of entrepreneurship', in Daniel Hjorth and Chris Steyaert (eds), Narrative and Discursive Approaches in Entrepreneurship: A Second Movement in Entrepreneurship Book, Cheltenham, UK and Northampton, MA, USA: Edward Elgar Publishing, pp. 8-21.

Steyaert, Chris and Daniel Hjorth (2006), Entrepreneurship As Social Change: A Third New Movements in Entrepreneurship Book, Cheltenham, UK and Northampton, MA, USA: Edward Elgar Publishing.

Steyaert, Chris and Pascal Dey (2010), 'Nine verbs to keep the social entrepreneurship research agenda "dangerous", The Journal of Social Entrepreneurship, 1 (2), 231-54.

Steyaert, Chris, Olivier Germain and Amélie Jacquemin (2017), 'Positioning entrepreneurship studies between critique and affirmation: Interview with Chris Steyaert', Revue de l'Entrepreneuriat, 16 (1), 55-64.

Weiskopf, Richard and Chris Steyaert (2009), 'Metamorphoses in entrepreneurship studies: towards an affirmative politics of entrepreneuring', in Daniel Hjorth and Chris Steyaert (eds), The Politics and Aesthetics of Entrepreneurship, Cheltenham, UK and Northampton, MA, USA: Edward Elgar Publishing, pp. 183-201.

Wingo, Ajume H. (2003), Veil Politics in Liberal Democratic States, Cambridge: Cambridge University Press.

Wittgenstein, Ludwig (2001), Philosophical Investigations, Malden, MA: Blackwell Publishing.

Wolfe Thompson, Jennifer (2002), 'The death of the scholarly monograph in the humanities? Citation patterns in literary scholarship', Libri, 52, 121-36. 
Chris Steyaert and Pascal Dey - 9781783474127 Downloaded from PubFactory at 04/26/2023 12:27:49PM via free access 